\title{
Information Systems Curricula 2003
}

Jessica R. Porter, (E-mail: rhiannep@aol.com), Middle Tennessee State University Stan Gambill, (E-mail: sgambill@mtsu.edu), Middle Tennessee State University

\begin{abstract}
The goal of the study is to determine which courses are currently being offered in Information Systems (IS) undergraduate College of Business programs, to profile these curriculums, and to compare this profile to the most recent IS model curriculum--the IS 2002 Model Curriculum. Of 330 university web sites examined with potential IS undergraduate degree programs, 222 web sites were identified with complete information on program requirements. The resulting profile matches the IS 2002 Model in eight out of eleven courses with two Model courses being represented by two profile courses each and one profile course not matching a Model course.
\end{abstract}

\section{Information Systems Curricula 2003}

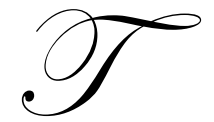

omorrow's professionals educated by the academic field of Information Systems rely upon university information systems departments to provide current and forward-looking instruction and education. According to the Occupational Outlook Handbook, 2002-03 Edition, the industry of computer and data processing services is projected to be "the fastest growing industry in the U.S. economy" (Bureau of Labor Statistics). As a result, systems analyst, computers scientist, and database administrator positions are expected to increase $36 \%$ or more, considered "much faster than the average" by the Bureau of Labor Statistics.

There is a strong demand placed on information systems instructors to educate students and to impart current and relevant knowledge. To succeed, information systems programs must maintain up to date course offerings. This is becoming increasingly difficult because of the constantly changing IT environment. Although technology fads cannot, and should not be incorporated into programs, an information systems program should not be viewed as timeless.

The goal of the study is to determine which courses are currently being offered in Information Systems (IS) undergraduate College of Business programs, to profile these curriculums, and to compare this profile to the most recent IS Curriculum Model--the IS 2002 Model Curriculum.

\section{Methodology}

Scope

The scope of this study included collecting course data from the web sites of information systems programs within colleges of business at universities in the United States. No distinctions were made between accredited and non-accredited universities or colleges of business. Course data were collected from accredited and non-accredited programs alike.

\section{Data Collection}

With this study, course data were collected via university web sites. In the previous study, surveys were sent to the program directors or chairpersons of information systems departments in colleges of business (Gambill, 1998; Maier, 1996). The preliminary list for the current study was drafted from the list of survey recipients. Added to the list from the previous study were universities appearing in online directories within the following sites: ISWorld Net, Link411, and Peterson's Education Portal. 
Attempts were made to gather data from 330 university web sites with 328 of those web sites belonging to U.S. universities. Two hundred twenty-two universities researched had a CIS business degree program, 72 had no CIS business degree program, and 34 were undetermined. Overall, data were collected from 222 U.S. universities with CIS business degree programs.

Over 150 hours were spent to gather all of the course data in this study. On average, each web site took just over 27 minutes. This time included moving from the University home page to the program page, locating the program's course information, and cataloguing the courses. Those university web sites that required more than the average time did so because they were unusually difficult to navigate. Several web sites seemed to lack a direct route to the needed information and, therefore, required much more time than the average.

\section{Results}

Overview

Of the eleven courses outlined in the IS ' 97 Model Curriculum, two courses were combined and one course was added to create the IS 2002 Model curriculum. IS '97.P0 - Knowledge Work and Software Tool Kit and IS ' 97.2 - Personal Productivity with IS Technology were merged to form IS 2002.P0 - Personal Productivity with IS Technology. IS 2002.2 - Electronic Business Strategy, Architecture and Design was added where there was not an IS '97 equivalent. The remaining courses were updated but maintained the same title. Appendices A and B list the IS ' 97 and 2002 Model Curriculum Course Topics for Undergraduate Degree Programs in Information Systems, respectively, to allow a topical comparison of the two models.

\section{Data Aggregation}

There were over 500 different required and elective course names identified in this research. The course information and tables that follow are aggregated numbers. For example, there may have been many names for a database course such as Database Applications, Database Concepts, Database Systems, Database Design, etc. However, in reporting the percentages, all these courses were reported under a single course name. This was done for all courses where there were several courses obviously in the same category.

\section{Profile and Comparison}

Table 1 lists the top 20 courses in rank order by percent of schools requiring the course for their IS majors. Table 2 lists the top 20 courses in rank order by percent of schools offering the course as an elective. Along with the course title and the percentage of programs requiring or offering the course as an elective, the corresponding IS 2002 Model Curriculum Course number is also listed. Courses not matching up with IS 2002 are listed as NA.

Table 3 shows a profile of CIS curriculum from the data gathered taking into account a combination of required and elective course. The number of required courses, and therefore elective courses, varies from program to program. The average number of courses required for the 222 programs researched was 6.6. The minimum, median, and maximum numbers of required courses were 0,7 , and 16 respectively. Table 3 shows a profile of a CIS curriculum as determined by data gathered from 222 programs in universities across the country. The median number of courses required by the 222 programs was used to determine the number of required courses listed in the profile.

The seven required courses in the profile are the top seven courses required by CIS programs as determined by the percentage of programs requiring the course. The number of elective courses was determined by simply subtracting the median of seven from the IS 2002 Model Curriculum course total of eleven. The four elective courses in the profile are the elective courses ranking three, four, five, and nine offered by CIS programs as determined by the percentage of programs offering the course as an elective. These were the top four ranked after courses were removed because they were in the top seven required courses. 
Table 1 Top 20 Required Courses

\begin{tabular}{|c|c|c|c|}
\hline Rank & Course & $\begin{array}{c}\text { Percentage } \\
\text { Requiring } \\
\text { Course }\end{array}$ & $\begin{array}{c}\text { IS } 2002 \\
\text { Model } \\
\text { Course } \\
\end{array}$ \\
\hline 1. & Programming Languages & $100 \%$ & 5 \\
\hline 2. & Database Systems & $72 \%$ & 8 \\
\hline 3. & Analysis \& Design Combine & $66 \%$ & 7 \\
\hline 4. & Data Communications & $55 \%$ & 6 \\
\hline 5. & Fundamentals of IS & $46 \%$ & 3 \\
\hline 6. & Computer Concepts & $45 \%$ & 1 \\
\hline 7. & Systems Analysis I & $32 \%$ & 7 \\
\hline 8. & Systems Analysis II & $32 \%$ & 9 \\
\hline 10. & Micro Computing & $18 \%$ & $\mathrm{P} 0$ \\
\hline 11. & Internet & $10 \%$ & 2 \\
\hline 12. & ES/DS/GDSS/AI & $9 \%$ & NA \\
\hline 13. & Operating Systems & $7 \%$ & NA \\
\hline 14. & Distributed Processing & $5 \%$ & NA \\
\hline 15. & Special Topics in IS & $5 \%$ & NA \\
\hline 16. & Business Systems and Information Systems & $4 \%$ & NA \\
\hline 17. & Software Engineering & $4 \%$ & NA \\
\hline 18. & Project Management & $3 \%$ & 10 \\
\hline 19. & Business Communications & $2 \%$ & NA \\
\hline 20. & Enterprise Systems (ERP) & $1 \%$ & NA \\
\hline
\end{tabular}

Table 2 Top 20 Elective Courses

\begin{tabular}{|c|c|c|c|}
\hline Rank & Course & $\begin{array}{c}\text { Percentage } \\
\text { Offering } \\
\text { Course } \\
\end{array}$ & $\begin{array}{c}\text { IS } 2002 \\
\text { Model } \\
\text { Course }\end{array}$ \\
\hline 1. & Programming Languages & $100 \%$ & NA \\
\hline 2 . & Fundamentals of IS & $54 \%$ & 3 \\
\hline 3. & Special Topics in IS & $45 \%$ & NA \\
\hline 4. & Internet & $42 \%$ & 2 \\
\hline 5. & ESS/DSS/GDSS/AI & $41 \%$ & NA \\
\hline 6. & Computer Concepts & $31 \%$ & 1 \\
\hline 7. & Data Communications & $26 \%$ & 6 \\
\hline 8. & Micro Computing & $24 \%$ & $\mathrm{P} 0$ \\
\hline 9. & Enterprise Systems (ERP) & $13 \%$ & NA \\
\hline 10. & Database & $11 \%$ & 8 \\
\hline 11. & Privacy \& Security & $10 \%$ & NA \\
\hline 12. & Systems Analysis \& Design Combined & $9 \%$ & 7 \\
\hline 13. & Operating Systems & $9 \%$ & NA \\
\hline 14. & Project Management & $8 \%$ & 10 \\
\hline 15 . & Systems Analysis I & $8 \%$ & 7 \\
\hline 16. & Systems Analysis II & $8 \%$ & 9 \\
\hline 17. & Business Systems \& Information Systems & $6 \%$ & NA \\
\hline 18. & Software Engineering & $6 \%$ & NA \\
\hline 19. & Business Communications & $6 \%$ & NA \\
\hline 20. & Distributed Processing & $3 \%$ & NA \\
\hline
\end{tabular}


As is evident by Table 3, not all of the courses in the IS 2002 Model appear in the profile. IS 2002.4 Information Technology Hardware and System Software and IS 2002.9 - Physical Design and Implementation in Emerging Markets were offered at less than 1\% of the schools. IS 2002.10 - Project Management and Practice was taught at only $8 \%$ of the schools. It is important to note that elements of these three courses are often taught in other courses. Another difference is that IS 2002 has one Analysis and Logical Design course and two courses that deal with physical design, IS $2002-8$ and 9. Seventy-five percent of the schools in the profile offer a single Systems Analysis and Design course.

Table 3 Profile of CIS Curriculum

\begin{tabular}{llcc}
\hline & & & IS 2002 \\
Rank & Course & $\begin{array}{c}\text { Required or } \\
\text { Elective }\end{array}$ & $\begin{array}{c}\text { Course } \\
\text { Cogramming Languages }\end{array}$ \\
\hline 1. & Progrel & 5 \\
2. & Systems Analysis \& Design Combined & $\mathrm{R}$ & 7 \\
3. & DBMS Concepts I & $\mathrm{R}$ & 8 \\
4. & Data/Telecommunications \& Networking & $\mathrm{R}$ & 6 \\
5. & Fundamentals of IS & $\mathrm{R}$ & 3 \\
6. & Computer Concepts & $\mathrm{R}$ & 1 \\
7. & Micro Computing & $\mathrm{R}$ & $\mathrm{P} 0$ \\
8. & Special Topics in IS & $\mathrm{E}$ & $\mathrm{NA}$ \\
9. & Internet Applications & $\mathrm{E}$ & $\mathrm{NA}$ \\
10. & DSS/ES/ESS/NN & $\mathrm{E}$ & 2 \\
11. & Enterprise Systems (ERP) & $\mathrm{E}$ & $\mathrm{NA}$ \\
\hline
\end{tabular}

In addition to the profile curriculum, it is interesting to note the extent to which select programming courses are offered at the 222 university programs researched. Table 4 provides information about programming courses offered in IS programs. The programming language courses offered as required or elective courses are listed in descending order by the percentage of programs offering the course as either a requirement or an elective. It is surprising to note that $\mathrm{COBOL}$ is still offered more often than any other programming language. Thirty-two percent require $\mathrm{COBOL}$ and another $32 \%$ offer $\mathrm{COBOL}$ as an elective course. Visual Basic is the second most offered programming course with $15 \%$ requiring the course and $10 \%$ offering it as an elective.

\section{Conclusion}

Although the most recent curriculum model prior to the IS 2002 Model Curriculum was the IS '97 Model Curriculum, very few changes were evident. Appendices A and B illustrate the differences between the two models in course topic description. The only true changes were the integration of two lower level courses into one and the addition of a course covering e-business and e-commerce. With the rapid growth and change occurring in the information systems field, it was expected that the model curriculum would be updated rather than undergoing a minor revision.

\section{Future Research}

The current IS Model Curriculum encompasses a single, general direction within the field of information systems in colleges of business; however, the needs and desires of students and the industry vary greatly. A singletrack CIS program does not suit the needs of every student working toward a CIS business degree. Additional research needs to be conducted to stimulate discussion and exploration with regard to the creation and implementation of multiple-track CIS business degree programs. 
Table 4 Percentage of Programs Requiring and/or Offering Select Programming Languages

\begin{tabular}{lccc}
\hline & $\begin{array}{c}\text { Percentage } \\
\text { Requiring } \\
\text { Course }\end{array}$ & $\begin{array}{c}\text { Percentage } \\
\text { Offering } \\
\text { Elective }\end{array}$ & $\begin{array}{c}\text { Percentage Offering } \\
\text { Course (Required } \\
\text { and/or Elective) }\end{array}$ \\
\hline COBOL & $32.4 \%$ & $31.5 \%$ & $64.0 \%$ \\
COBOL I & $20.3 \%$ & $14.9 \%$ & $35.1 \%$ \\
COBOL II & $9.0 \%$ & $11.7 \%$ & $20.7 \%$ \\
COBOL I and II Combined & $3.2 \%$ & $4.1 \%$ & $7.2 \%$ \\
Object-Oriented & $0.0 \%$ & $0.5 \%$ & $0.5 \%$ \\
Web Programming & $0.0 \%$ & $0.5 \%$ & $0.5 \%$ \\
C/C++ & $9.5 \%$ & $16.2 \%$ & $25.7 \%$ \\
Visual Basic & $15.3 \%$ & $10.4 \%$ & $25.7 \%$ \\
Business Programming (language na) & $15.3 \%$ & $9.5 \%$ & $24.8 \%$ \\
Object-Oriented Programming (language na) & $7.7 \%$ & $17.1 \%$ & $24.8 \%$ \\
Java & $3.6 \%$ & $9.9 \%$ & $13.5 \%$ \\
Survey of Computer Languages & $3.6 \%$ & $4.1 \%$ & $7.7 \%$ \\
Other Programming Languages (language na) & $0.0 \%$ & $5.0 \%$ & $5.0 \%$ \\
BASIC & $1.8 \%$ & $1.8 \%$ & $3.6 \%$ \\
Assembly Language & $0.9 \%$ & $1.4 \%$ & $2.3 \%$ \\
RPG & $0.0 \%$ & $2.0 \%$ & $2.0 \%$ \\
PASCAL & $0.0 \%$ & $1.0 \%$ & $1.0 \%$ \\
CICS Application Programming & $0.0 \%$ & $1.0 \%$ & $1.0 \%$ \\
FORTRAN & $0.0 \%$ & $1.0 \%$ & $1.0 \%$ \\
\hline
\end{tabular}

Comparison of IS '02 Curriculum Model and the "Typical IS Curriculum"

\begin{tabular}{|l|l|}
\hline IS '02 Courses & Curriculum Profile \\
\hline Personal Productivity with IS Technology & $\begin{array}{l}\text { Microcomputer Applications } \\
\text { Required 18\% Elective 24\% }\end{array}$ \\
\hline Fundamentals of Information Systems & $\begin{array}{l}\text { Fundamentals of Information Systems } \\
\text { Required 46\% Elective 54\% }\end{array}$ \\
\hline $\begin{array}{l}\text { Electronic Business Strategy, } \\
\text { Architecture and Design }\end{array}$ & $\begin{array}{l}\text { Internet } \\
\text { Required 10\% Elective 42\% }\end{array}$ \\
\hline Information Systems Theory and Practice & $\begin{array}{l}\text { Computer Concepts } \\
\text { Required 45\% Elective 31\% }\end{array}$ \\
\hline Information Technology Hardware and System Software & \\
\hline $\begin{array}{l}\text { Programming, Data, File and } \\
\text { Object Structures }\end{array}$ & $\begin{array}{l}\text { Programming Courses } \\
\text { Required 100\% Elective 100\% }\end{array}$ \\
\hline Networks and Telecommunication & $\begin{array}{l}\text { Data Communications } \\
\text { Required 55\% Elective 26\% }\end{array}$ \\
\hline Analysis and Logical Design & $\begin{array}{l}\text { Systems Analysis \& Design* } \\
\text { Required 90\% Elective 5\% }\end{array}$ \\
\hline $\begin{array}{l}\text { Physical Design and Implementation } \\
\text { with DBMS }\end{array}$ & $\begin{array}{l}\text { Database } \\
\text { Required 72\% Elective 11\% }\end{array}$ \\
\hline $\begin{array}{l}\text { Physical Design and Implementation } \\
\text { in Emerging Environments }\end{array}$ & \\
\hline Project Management and Practice & \multicolumn{2}{|l}{} \\
\hline
\end{tabular}

* Most schools (75\%) teach a combined SAD: ES/DSS/GDSS/AI Not accounted for in IS '02 


\section{References}

1. Bureau of Labor Statistics, U.S. Department of Labor. Systems Analysts, Computer Scientists, and Database Administrators. Occupational Outlook Handbook, 2002-03 Edition. Retrieved February 11, 2003, from http://www.bls.gov/oco/ocos042.htm

2. Davis, G. B., Gorgone, J. T., Couger, J. D., Feinstein, D. L., Longenecker, H. E. (1997). "IS '97 Model Curriculum and Guidelines for Undergraduate Degree Programs in Information Systems". Association of Information Technology Professionals.

3. Gambill, S. E. \& Maier, J. L. (1998, Fall/Winter). "CIS/MIS Curriculums in AACSB and Non-AACSB Accredited Colleges of Business". Journal of Information Systems Education, 9(1 \& 2), 59-63.

4. Gorgone, J. T., Davis, G. B., Valacich, J. S., Keikki, T., Feinstein, D. L., Longnecker, H. E., Jr. (2002). "IS 2002 Model Curriculum and Guidelines for Undergraduate Degree Programs in Information Systems". Association of Information Systems.

5. ISWorld Net. Retrieved September 2001 from http://mcs.uww.edu/isprogug/namelist.htm (no longer exists at this location) and http://juliet.stfx.ca/ rmackinn/infosys/na.htm\#usa

6. Link411. Retrieved September 2001 from http://www.link411.com/colleges.htm (no longer exists at this location).

7. Maier, J. L. \& Gambill, S. E. (1996, July/August). "CIS/MIS Curriculums in AACSB-Accredited Colleges of Business|". Journal of Education for Business, 71(6), 329-333.

8. Peterson's Education Portal. Retrieved September 2001 from http://www.petersons.com

\section{Appendix A}

IS '97 Model Curriculum Course Topics for

Undergraduate Degree Programs in Information Systems*

\begin{tabular}{|c|c|c|}
\hline \multicolumn{2}{|c|}{ Course } & \multirow{2}{*}{$\begin{array}{l}\text { Course Topic } \\
\text { Word processing, E-mail, Internet tools, spreadsheets, databases, presentation graphics, } \\
\text { external database retrieval, introduction to statistical software. }\end{array}$} \\
\hline P0 & $\begin{array}{l}\text { Knowledge Work } \\
\text { Software Tool Kit }\end{array}$ & \\
\hline 1 & $\begin{array}{l}\text { Fundamentals of } \\
\text { Information Systems }\end{array}$ & $\begin{array}{l}\text { Systems concepts; system components and relationships; cost/value and quality of } \\
\text { information; competitive advantage of information; specification, design, and re-engineering } \\
\text { of information systems; application versus system software; package software solutions; } \\
\text { procedural versus non-procedural programming languages; object oriented design; database } \\
\text { features, functions, and architecture; networks and telecommunication systems and } \\
\text { applications; characteristics of IS professionals and IS career paths. }\end{array}$ \\
\hline 2 & $\begin{array}{l}\text { Personal Productivity } \\
\text { with IS Technology }\end{array}$ & $\begin{array}{l}\text { End user systems versus organization systems; analysis of knowledge work and its } \\
\text { requirements; knowledge work productivity concepts; software functionality to support } \\
\text { personal and group productivity; organization and management of software and data; } \\
\text { accessing organization data, accessing external data; selecting a computer solution; developing } \\
\text { a macro program by doing; designing and implementing a user interface; developing a } \\
\text { solution using database software; refining and extending individual and group information } \\
\text { management activities. }\end{array}$ \\
\hline \multicolumn{2}{|c|}{ Course } & Course Topic \\
\hline 3 & $\begin{array}{l}\text { Information Systems } \\
\text { Theory and Practice }\end{array}$ & $\begin{array}{l}\text { Systems theory and concepts; information systems and organizational systems; decision theory } \\
\text { and how it is implemented by IT, TQM and reengineering; level of systems: strategic, tactical, } \\
\text { and operational; system components and relationships; information systems strategies; roles of } \\
\text { information and information technology; roles of people using, developing, and managing } \\
\text { systems; IS planning; human-computer interface; network and telecommunications systems } \\
\text { management; electronic commerce; implementation and evaluation of system performance; } \\
\text { societal and ethical issues related to information systems design and use. }\end{array}$ \\
\hline 4 & $\begin{array}{l}\text { Information } \\
\text { Technology } \\
\text { Hardware and } \\
\text { Software }\end{array}$ & $\begin{array}{l}\text { Hardware: CPU architecture, memory, registers, addressing modes, busses, instruction sets, } \\
\text { multi processors versus single processors; peripheral devices: hard disks, CDs, video display } \\
\text { monitors, device controllers, input/output; operating systems functions and types; operating } \\
\text { system modules: processes, process management, memory and file system management; } \\
\text { examples of operating systems; basic network components, switches, multiplexers and media; } \\
\text { installation and configuration of multiuser operating systems. }\end{array}$ \\
\hline
\end{tabular}




\begin{tabular}{|c|c|c|}
\hline 5 & $\begin{array}{l}\text { Programming, Data } \\
\text { and Object Structures }\end{array}$ & $\begin{array}{l}\text { Data structures and representation: characters, records, files, multimedia; precision of data; } \\
\text { information representation, organization, and storage; algorithm development; object } \\
\text { representation compared to conventional data flow notation; programming control structures; } \\
\text { program correctness, verification, and validation; file structures and representation. }\end{array}$ \\
\hline \multicolumn{2}{|c|}{ Course } & Course Topic \\
\hline 6 & $\begin{array}{l}\text { Networks and } \\
\text { Telecommunication }\end{array}$ & $\begin{array}{l}\text { Telecommunication devices, media, systems; network hardware and software; network } \\
\text { configuration; network applications; coding of data; cost benefit analysis; distributed versus } \\
\text { centralized systems; architectures, topologies, and protocols; installation and operation of } \\
\text { bridges, routers and gateways; network performance analysis; privacy, security, reliability; } \\
\text { installation and configuration of LAN and WAN networks; monitoring of networks; } \\
\text { management of telecommunications, and communications standards. Intranet and internet. }\end{array}$ \\
\hline 7 & $\begin{array}{l}\text { Analysis and Logical } \\
\text { Design }\end{array}$ & $\begin{array}{l}\text { Life cycle phases: requirements determination, logical design, physical design, test planning, } \\
\text { implementation planning, and performance evaluation; communication, interpersonal skills, } \\
\text { interviewing, presentation skills; group dynamics; risk and feasibility analysis; group-based } \\
\text { approaches: project management, joint application development (JAD), and structured } \\
\text { walkthroughs; object oriented design; software production and reviews; prototyping; database } \\
\text { design; software quality metrics; application categories; software package evaluation and } \\
\text { acquisition; professional code of ethics. }\end{array}$ \\
\hline 8 & $\begin{array}{l}\text { Physical Design and } \\
\text { Implementation with } \\
\text { DBMS }\end{array}$ & $\begin{array}{l}\text { Data models and modeling tools/techniques; structured and object design approaches; models } \\
\text { for databases: relational, hierarchical, networked and object oriented designs; CASE tools; } \\
\text { data dictionaries, repositories, warehouses; implementation: Windows GUI coding and/or } \\
\text { implementation, codelapplication generation; client-server planning, testing, and } \\
\text { installations; system conversion, end user training/integration and post implementation } \\
\text { review. }\end{array}$ \\
\hline \multicolumn{2}{|c|}{ Course } & Course Topic \\
\hline 9 & $\begin{array}{l}\text { Physical Design and } \\
\text { Implementation with } \\
\text { Programming } \\
\text { Environments }\end{array}$ & $\begin{array}{l}\text { Selection of client-server programming language environment; software construction: } \\
\text { structured, event driven, and object oriented application design; testing; software quality } \\
\text { assurance; system implementation; user training; system delivery; post implementation } \\
\text { review; configuration management; maintenance; reverse engineering and re-engineering. } \\
\text { Both full client and thin-browser active server based approaches are considered. }\end{array}$ \\
\hline 10 & $\begin{array}{l}\text { Project Management } \\
\text { and Practice }\end{array}$ & $\begin{array}{l}\text { Managing the system life cycle: requirements determination, logical design, physical design, } \\
\text { testing, implementation; system and database integration issues; network and client-server } \\
\text { management; metrics for project management and system performance evaluation; managing } \\
\text { expectations: superiors, users, team members and others related to the project; determining } \\
\text { skill requirements and staffing the project; cost-effectiveness analysis; reporting and } \\
\text { presentation techniques; effective management of both behavioral and technical aspects of the } \\
\text { project; change management. }\end{array}$ \\
\hline
\end{tabular}

* Italicized text denotes deletions from the topic description when the IS '97 Model was updated to the IS 2002 Model.

Appendix B

IS 2002 Model Curriculum Course Topics for

Undergraduate Degree Programs in Information Systems*

\begin{tabular}{|l|l|l|}
\hline \multicolumn{2}{|l|}{ Course } & Course Topic \\
\hline P0 & $\begin{array}{l}\text { Personal Productivity } \\
\text { with IS Technology }\end{array}$ & $\begin{array}{l}\text { Knowledge work productivity concepts; advanced software functionality to support personal } \\
\text { and group productivity concepts using functions and features in computer software such as } \\
\text { spreadsheets, databases, presentation graphics, and Web authoring. Although identified as a } \\
\text { course, this material can be delivered as self-study modules, as modules associated with other } \\
\text { courses using the software, or as a full course. }\end{array}$ \\
\hline 1 & $\begin{array}{l}\text { Fundamentals of } \\
\text { Information Systems }\end{array}$ & $\begin{array}{l}\text { Systems concepts; system components and relationships; cost/value and quality of information; } \\
\text { competitive advantage of information; specification, design, and re-engineering of information } \\
\text { systems; application versus system software; package software solutions; procedural versus } \\
\text { non-procedural programming languages; object oriented design; database features, functions, } \\
\text { and architecture; networks and telecommunication systems and applications; characteristics of } \\
\text { IS professionals and IS career paths; information security, crime, and ethics. Practical exercises } \\
\text { may include developing macros, designing and implementing user interfaces and reports; } \\
\text { developing a solution using database software. }\end{array}$ \\
\hline
\end{tabular}




\begin{tabular}{|c|c|c|}
\hline \multicolumn{2}{|c|}{ Course } & \multirow[b]{2}{*}{$\begin{array}{l}\text { Course Topic } \\
\text { Electronic commerce economics, business models, value chain analysis, technology } \\
\text { architectures for electronic business, supply chain management, consumer behavior within } \\
\text { electronic commerce environments, legal and ethical issues, information privacy and security, } \\
\text { transborder data flows, information accuracy and error handling, disaster planning and } \\
\text { recovery, solution planning, implementation and rollout, site design, Internet standards and } \\
\text { methods, design of solutions for the Internet, intranets, and extranets, EDI, payment systems, } \\
\text { support for inbound and outbound logistics. }\end{array}$} \\
\hline 2 & $\begin{array}{l}\text { Electronic Business } \\
\text { Strategy, Architecture } \\
\underline{\text { and Design }}\end{array}$ & \\
\hline 3 & $\begin{array}{l}\text { Information Systems } \\
\text { Theory and Practice }\end{array}$ & $\begin{array}{l}\text { Systems theory and concepts; information systems and organizational systems; decision } \\
\text { support; quality; level of systems: strategic, tactical, and operational; system components and } \\
\text { relationships; information systems strategies; roles of information and information technology; } \\
\text { roles of people using, developing, and managing systems; IS planning and change } \\
\text { management; human-computer interface; IS development process; evaluation of system } \\
\text { performance; societal and ethical issues related to information systems design and use. }\end{array}$ \\
\hline 4 & $\begin{array}{l}\text { Information } \\
\text { Technology Hardware } \\
\text { and System Software }\end{array}$ & $\begin{array}{l}\text { Hardware: CPU architecture, memory, registers, addressing modes, busses, instruction sets, } \\
\text { multi processors versus single processors; peripheral devices: hard disks and other storage } \\
\text { devices, video display monitors, device controllers, input/output; operating systems functions } \\
\text { and types; operating system modules: processes, process management, memory and file system } \\
\text { management; examples and contrasts of hardware architectures and operating systems. }\end{array}$ \\
\hline \multicolumn{2}{|c|}{ Course } & Course Topic \\
\hline 5 & $\begin{array}{l}\text { Programming, Data, } \\
\text { File and Object } \\
\text { Structures }\end{array}$ & $\begin{array}{l}\text { Data structures and representation: characters, records, and files; precision of data; information } \\
\text { representation, organization, and storage; algorithm development; programming control } \\
\text { structures; program correctness, verification, and validation; file structures and representation. } \\
\text { Programming in traditional and visual development environments that incorporate event- } \\
\text { driven, object-oriented design. }\end{array}$ \\
\hline 6 & $\begin{array}{l}\text { Networks and } \\
\text { Telecommunication }\end{array}$ & $\begin{array}{l}\text { Telecommunication configurations; network and Web applications; distributed systems; wired } \\
\text { and wireless architectures, topologies, and protocols; installation, configuration, and operation } \\
\text { of bridges, routers, switches, and gateways; network performance tuning; privacy, security, } \\
\text { firewalls, reliability; installation and configuration of networks; monitoring and management of } \\
\text { networks; and communications standards. }\end{array}$ \\
\hline 7 & $\begin{array}{l}\text { Analysis and Logical } \\
\text { Design }\end{array}$ & $\begin{array}{l}\text { Life cycle phases: requirements determination, logical design, physical design, and } \\
\text { implementation planning; interpersonal skills, interviewing, presentation skills; group } \\
\text { dynamics; risk and feasibility analysis; group-based approaches: project management, joint } \\
\text { application development (JAD), and structured prototyping; database design; software package } \\
\text { evaluation, acquisition, and integration; global and inter-organizational issues and system } \\
\text { integration; professional code of ethics. }\end{array}$ \\
\hline \multicolumn{2}{|c|}{ Course } & Course Topic \\
\hline 8 & $\begin{array}{l}\text { Physical Design and } \\
\text { Implementation with } \\
\text { DBMS }\end{array}$ & $\begin{array}{l}\text { Conceptual, logical, and physical data models, and modeling tools; structured and object design } \\
\text { approaches; models for databases: relational and object oriented; design tools; data } \\
\text { dictionaries, repositories, warehousing, and data mining; database implementation including } \\
\text { user interface and reports; multi-tier planning and implementation; data conversion and post } \\
\text { implementation review. }\end{array}$ \\
\hline 9 & $\begin{array}{l}\text { Physical Design and } \\
\text { Implementation in } \\
\text { Emerging } \\
\text { Environments }\end{array}$ & $\begin{array}{l}\text { Topics may include selection of development environments and standards; structured, event } \\
\text { driven, and object oriented application design; testing; software quality assurance; system } \\
\text { implementation; user training; system delivery; post implementation review; configuration } \\
\text { management; maintenance; multi-tiered architectures and client independent design. }\end{array}$ \\
\hline 10 & $\begin{array}{l}\text { Project Management } \\
\text { and Practice }\end{array}$ & $\begin{array}{l}\text { Managing the system life cycle: requirements determination, design, implementation; system } \\
\text { and database integration issues; network management; project tracking, metrics, and system } \\
\text { performance evaluation; managing expectations of managers, clients, team members, and } \\
\text { others; determining skill requirements and staffing; cost-effectiveness analysis; reporting and } \\
\text { presentation techniques; management of behavioral and technical aspects of the project; change } \\
\text { management. Software tools for project tracking and monitoring. Team collaboration } \\
\text { techniques and tools. }\end{array}$ \\
\hline
\end{tabular}

